\title{
MYSTICISM ELEMENTS IN THE USE OF FIREARM TECHNOLOGY IN THE MANUSCRIPT ON FIREARMS
}

\author{
Pramono* \\ Wan Mohd Dasuki Wan Hasbullah** \\ Herry Nur Hidayat ${ }^{* * *}$
}

\begin{abstract}
:
In the realm of Malay manuscript researches, the aspect of technology has been given little attention to be researched in a serious and specific manner. Even less is the study focused on the correlation between the Malay technology and Islamic civilization. This article seeks to shed light on the matter and discusses the Malay technology dealing with the use of hand-held firearms which was possibly inherited from the Islamic sources found in the Malay manuscripts. In particular, this article tries to analyse the mysticism elements which seems to be the underlying idea of the indigenous knowledge of firearm technology. The knowledge of such technology and its application are believed to have been practiced by individuals or groups of individuals in the Malay civilization till the 19th mid-century.
\end{abstract}

Keywords: firearms, indigenous knowledge, Malay manuscript, Malay technology, Mysticism

\begin{abstract}
ABSTRAK
Dalam khazanah penelitian manuskrip Melayu, aspek teknologi masih minim dijadikan objek kajian yang khusus dan serius. Terlebih lagi, kajian yang difokuskan pada hubungan teknologi Melayu dengan peradaban Islam. Artikel ini dimaksudkan untuk mengisi kekosongan kajian tersebut. Artikel ini membahas teknologi bangsa Melayu dalam hal penggunaan senjata api atau "bedil" (senapan) yang kemungkinan diwarisi dari sumber Islam; dengan bersumber dari manuskrip Melayu. Secara khusus, tulisan ini menganalisis unsur-unsur tasawwuf yang menjadi dasar pemikiran dalam teknologi ilmu bedil. Pengetahuan mengenai teknologi dan aplikasinya diyakini telah dipraktikkan oleh individu tertentu atau sekelompok individu dalam kebudayaan Melayu sampai pertengahan abad ke-19.
\end{abstract}

Kata kunci: bedil, naskah Melayu, pengetahuan pribumi, tasawuf, teknologi Melayu

\footnotetext{
* Faculty of Humanities Andalas University at Limau Manis Campus.

** School of Humanities, Universiti Sains Malaysia, Pulau Pinang.

*** Faculty of Humanities Andalas University at Limau Manis Campus.
} 


\section{INTRODUCTION}

Islamic civilization significantly contributed to the development of the Malay world in the field of science and technology. Islam brought enlightenment to the Malay people by stressing the science, that is, "by way of manner and style of seeing something in a scientific way" (al-Attas, 1992: 20-21, 31). The Islamic civilization, which had then been based on science, became the prominent factor in developing the Malay culture and thoughts.

In this context, the Malay scholars succeeded in adjusting the Arabic scripts used to write Malay/ Indonesian texts using Jawi alphabets, which later played an important role as the language for science and lingua franca in the region. Cultural records written in Jawi were socially responsible for the socialization and spread of Islamic teachings in the Southeast Asia (Purwana, 2001: 83). Even more so, Jawi script brought a positive impact to the Malay language and became a language for communication, science, and written literary works. Jawi undoubtedly played an important role in stimulating the Malay scientific development and creativity as seen through the writing of manuscripts containing various types of texts such as literary works, history, religion, and indigenous knowledge.

Discussion about science with Islamic components which are enclosed in the Malay manuscripts cannot be confined to works merely specializing in religious affairs. Instead, the religious aspects heavily influenced the structure of the Malay thoughts, as clearly depicted in the works related to the aspects of science and technology of the traditional Malay society. These can be observed in the fields of navigation, astronomy, medication, house construction, and so forth. Such nature of works, according to Piah, et al. (2006), are called "the scientific literature of traditional Malay". It is a particular genre of traditional Malay literary work, which is not only scientific, but also includes both lessons and beliefs in relation to their daily lives. It is taken as a corpus of knowledge of the Malay civilization written in particular style and idioms in accordance to its contents, which includes numerous belief features, particularly dealing with mysticism. In other words, most works in this genre prioritize 'mystical elements' as a major element of belief which was revered as gospel which was painstakingly adhered to when certain indigenous knowledge was being practiced; the knowledge of firearm technology as a case in point.

However, the discussion here is not aimed at elaborating the position of mysticism in the framework of religious thoughts of the traditional Malay society. Instead, it highlights the influence of the element of mysticism with regards to the knowledge and Malay tradition in the context of its application to firearm technology. Simultaneously, the discussion will also highlight some examples in the case of the domestication of alien technology - based on firearm - into their tradition and culture. In other words, the objectives of this writing are to discuss the relation of mysticism with the technological aspects in order to evaluate their roles and functions and to investigate the interpretation of the alien technology as far as the content of the manuscripts can tell, through textual analysis. Consequently, this article is expected to shed some light to the exploration with regards to the literary works using the corpus of traditional knowledge. Particular emphasis is aimed at strengthening the framework of analysis and elaboration of the Malay traditional texts, in relation to the technology, science and belief in the Malay culture.

The manuscripts to be referred to and discussed in this article are the Koleksi Naskah Ilmu Bedil (Collection of the Manuscripts on Firearm), henceforth called KNIB.

\section{THE ACQUISITION OF MALAY'S FIREARMS TECHNOLOGY}

Islam played an important role in introducing Malays to the firearms technology. Many scholars have no objection to the statement; among them are Crawfurd (1974), Woolley (1998); GibsonHill (1953), Harisson (1969), Andaya (1999), Ali (1995), Khan (1996) and Al-Hassan (1986). From the historical point of view, it is interesting to observe that there was a relation between Aceh and the Ottoman empire during the 16th century A.D; the manuscripts showed how both sides seriously formed an alliance in the field of weaponry (chiefly in artillery) to fight the Christians. The Turks-Aceh relation was principally a sort of religious bond. 
This situation made it easier for firearm technology $\mathrm{t}$ be accepted by the Malay world, although the power of the Ottoman empire was starting to decline during that period. In relation to this, Reid (1969: 395-414) writes that the early contact of Aceh-Turks was initiated since 1537 A.D. It is written in one of the documents that belongs to the Ottoman informing the appeal on the part of Aceh to be supplied with rifles and artillery experts to fight against the Portuguese-Malacca from 1567 to 1568 A.D.

Malay people traditionally used the term 'bedil' (rifle) to refer to any kinds of firearms. If traced through the historical texts and Malay annals, various names for rifle were given, such as lela, lela rentaka, ekor lotong, jinjal, tahan turut, meriam, jala rembang, istinggar, pemburas, senapang terkul, senapang kopak, and so on. The various names given in one way or another indicated the extensive knowledge of the Malays in distinguishing one kind of rifle from another which they had possibly made and used.

It can be concluded the relation between the Malay region and the Middle East as the sources of civilization and science had been established early, even before the arrival of the Europeans. Moreover, it is estimated the Malays already knew how to make ammunition of the rifles and how to produce saltpetre and sulphur abundantly found in the Malay archipelago. Saltpetre, in Malay terminology, is called "mesiyu" or "sendawa" (gunpowder). Saltpetre was combined with sulphur and carbon in an exact measurement before it was blended and filled into the bamboo shuttle to make it easier to be loaded into the rifle (Soegondo, 1954: 115 \& McNair, 1972: 255).

In line with this opinion, Crawfurd (1974: 22-23) also referred to the Arabs/Islams when he was explaining the origins of where the Malays acquired their firearms technology. Crawfurd believed that it was the Arabs who brought the term "meriam" to the Malay community. Likewise, it is reported that other kinds of matchlock rifles made by Persians and Moghul-Indians were spread over East or the land of Malay (Ali, 1995: 117-119). At the end of 16th century A.D, the western firearms technology also began to spread as a result of their exploration. As a consequence, the Malay began to make adaptation to the use of firearms, particularly the rifle family, like the matchlock arquebus or espingarda, despite of facing some difficulties. Subsequently, the use of western firearms became popular among the Malay and continued to do so as western civilization develop their science and technology including advancements in the field of weaponry and war tactics.

\section{COLLECTION OF MANUSCRIPTS ON FIREARMS}

There are six manuscripts discussing Malay firearm technology of the (all of them are mentioned in the KNIB) and each of them is documented at:

a. Pusat Dokumentasi Melayu, Dewan Bahasa \& Pustaka Kuala Lumpur (Centre for Malay Documentation, Dewan Bahasa \& Pustaka Kuala Lumpur) comprising three texts: MS31 and MS101 (composed of two parts, namely A and B). These texts have been transliterated and published (Ahmad, 1984).

b. Pusat Manuskrip Melayu, Perpustakaan Negara Malaysia, Kuala Lumpur (Centre for Malay Manuscript, Malaysian National Library, Kuala Lumpur), comprising two texts: MS 1380 and MS 1922 (part B).

c. Perpustakaan Perbadanan Muzium Negeri Terengganu (Library of State Museum Board of Terengganu), comprising manuscripts no. 85.48.

According to the entry of Katalog Induk Manuskrip Perpustakaan Negara Malaysia (Catalogue of manuscript Centre of Malaysian National Library) (1993) and subsequent supporting catalogues, as well as the Katalog Manuskrip Melayu Koleksi Pusat Dokumentasi Melayu Dewan Bahasa \& Pustaka (Catalogue of Malay Manuscripts, a collection of Centre for Malay Documentation, Board of Language and Library) (2006), all of the above-mentioned manuscripts directly mention the use of firearms. However, it is likely that some manuscripts on firearms have yet to be found. Attempts to acquire those manuscripts turn out to be rather difficult because their existence is included in the title of unknown manuscripts (Zain, 2005: 207-211). In addition, the 
entry of manuscript title written in the catalogues does not directly imply its content. For example, MS101 is referred to as "Kitab Tib" - Book of Tib - (in Arabic, the word "tib" means "medicine", in which firearms does not play any part of.

In KNIB, the text included in the MS101 needs more elaboration as it belongs to a colophon dated 1280 Hijri (1863 A.D). The manuscript suffers from unclear dating, which was in middle of $19^{\text {th }}$ century A.D. At the same time, it is necessary to underline the possibility of this text as having been studied or practiced before the era. It is due to its technological subject matter which explains the direction of use of espingarda (a sort of matchlock firearms claimed to be introduced by the Portuguese during the 16th century A.D). Meanwhile, in $19^{\text {th }}$ century A.D, the Malays had already used rifles (Gullick, 1978:173-175). Besides, based on the construction of the content, text MS31 and 85.48 resembles MS101; which indicates the possibility that both were rewritten from MS101 or simply a copy of the main text MS101.

The content of the KNIB documents the ways Malays used their firearms; particularly the shoulder weapon. Based on initial observation, the contents cover the followings:

a. direction of pointing and fixing the target of shooting [technical + mysticism element]

b. ignition of arms [technical]

c. basics of shooting [technical + mysticism element]

d. direction of aiming [technical + mysticism element]

e. ingredients and measurement of ammunition [technical + ethnomathematics]

f. concept and philosophy of shooting [mysticism element]

g. use of rituals, a certain spells (mantra before and while shooting [mystic element of older belief + mysticism element]

It is pertinent to note that the structure and content of text MS1380 and MS1922 differ from the other three texts, namely MS31, MS101 and Text 85.48. While the 2 prior texts contained a brief explanation on ritual aspects and spells related to the shooting precision, the three main texts deal with physical aspects, theories, and the philosophy of shooting. However, it can be safely concluded that all of the texts depict mysticism elements and mystics either the theory and practice of shooting or for forms of spell recitation.

\section{MYSTICISM ELEMENTS IN THE KNIB}

Simply put, mysticism is the knowledge of how Muslims align themselves closer to God (Hassan, 1988: 10). Mysticism is a method to train the soul (spirit) so that it becomes pure and clean, particular qualities which are taken as prerequisites of knowing God ( $m a$ 'rifat $=$ gnosis) in the most decent and proper ways for servants of God. Imam Junaid al-Baghdadi once said that mysticism means to clean the soul by restraining one's passions, to eradicate bashariyyat characters, to exercise spiritual characters, and to hold fast to Sharia (Islamic canon law) (Halim, 1999: 10). Mysticism shows the righteous path to humankind in order to achieve closeness and intimacy with God (Manshur, 1999: 102). It follows from this that the key notion of mysticism is pertinent with soul and good deeds. There are two sects of mysticism: of Sunni (according to the belief of ahlu'l-sunnat $w a$ ' l-jamā'at) and of philosophy. Unlike the former, the latter explains about truth of divinity, nature, and their relation to humankind through in-depth thinking. Philosophical mysticism is also associated with the sect of wahdatu'l- wujūd.

The sect of wahdatu'l- wujüd is a doctrine of sufism well known to the Malay world. Its teachings deal with the unity of God's being and nature and humankind. According to this doctrine, God reveals Himself in a manner of seven dignities which constitute a series of alteration or tajalli (manifestation) and of whose formation are in stages in elaborating the process of creation of universe and God's entity as the one and only. Each of the tajalli represents one aspect of God. The doctrine introduces the notion of the unity of existence or wujūdiyyat of the teachings of mystical philosophy of Muhyiddin ibn Arabi (Adam, 2009a: 87-88).

Hassan (1988: 4-7) says that Malay manuscripts on literary works in the past indeed expose ample of philosophical mysticism elements. 
Unlike the situation of the literary works before the coming of Islam which was centred on the royal palaces, the literary works under the influence of Islam (a literary book of mysticism) spread over the regions: outside the palace (Istanti, 2001: 23). Moreover, philosophical mysticism became the topic of discussion in spoken as well as in written medium of communication and was included in attempts to produce new literary works either in the form of prose or poetry. The philosophical mysticism was also absorbed in public art and entertainment like puppet show (wayang kulit). A comical character named Semar or Dogol was given a mystical role who had vast knowledge about "sharī'at?" (sharia), "tariqqat" (mystic path to the truth), "haqiqat”" (Divine Truth), and "ma 'rifat." (mystical knowledge of the Godhead).

In addition to its mystical nature and the role of symbolism as the sources of attractiveness, the popularity of the sect was also enhanced by the spread of Islamic teachings performed by the pioneers of this very sect (Johns, 1974: 117; Adam, 2009a: 88). As such, the philosophical mysticism was viewed in a different way due to its mystical and magical or spiritual characteristics. Trimingham (1971: 21) supports this notion by arguing that tariqqat in mysticism has advantages due to its magical properties as a power of symbolism achieved by reciting certain passages of the Koran. For many researchers, such situations pave the way to show the continuity of the Malays' old school of thought, which relates to the symbolism of objects.

Based on KNIB, the elements of mysticism can be explained by investigating several keywords that refer to the doctrine of the above-mentioned sect. The contents of the manuscripts show many keywords in use. KNIB covers various ways of uses and subject matters either being arranged in the form of scientific description within texts or the incantation of spells. The concepts of mysticism included in the KNIB are provided below. In the explanation, these concepts are not compared to the basic thought of philosophical mysticism. This is to avoid misunderstandings in this article. KNIB is understood according to the attempts to illustrate the application of philosophical mysticism dealing with technological aspects and shooting techniques.

\section{a. The Concept of Rabittat}

According to KNIB the concept of rabit tat refers to the special ways or practices when aiming the rifle and the actual act of shooting. One of the examples is while holding on the rifle, as quoted below:

“...seperti orang rabițah ralibkan pandangannya itu, kemudian tekan kuatkuat, genggamlah tangan yang sebelah kanan biar kuat-kuat, yang sebelah kiri ampu sahaja janganlah dikuat sekali-kali adanya; dan lagi petiknya itu janganlah dikuatkan.” [MS101A, hlm. 2]

“... like one practicing rabitah, aim at the target, hold the rifle tight with the right hand and support it with the left hand and pull the trigger just enough." [MS101A, hlm. 2]

Such practice is meant to make his teacher's shadow clearer. The firing pin is only pulled after he sees his teacher's image clearly; indicating the strong bond between pupil and master. This process shows the existence of tawajjuh with the master, in which, the master, in turn, will bridge the intention of the pupil to God (the One in power to realize the pupil's desire). This practice shows the way to aim a rifle and, at the same time, to arouse belief in the pupil's knowledge so that he can shoot on target. This is explained in the quoted text below:

“...jikalau kita hendak menembak terakul itu, niatkan terakul itu seumpama satu sarung dengan alamat. Apabila tiga-tiga itu sudah bersatu baharulah niatkan seperti tawajjuh dengan guru. Pandanglah guru itu biar nyata-nyata. Pandanglah dengan mata yang halus. Adalah tuhan itu dihadapan kita, tampaklah pada mata yang batin..." [MS101A, hlm. 4].

"... if we want to fire the terakul (flintlock musket), imagine the rifle and the target as being in a single sheath (so that we won't miss the target). After the three (terakul, sheath, and target) are united, then make a strong wish for tawajjuh with your master. Imagine seeing your master in real time and look upon him with a modest look. Wish for the God's presence in front of us as it will 
open our innermost feelings ..." [MS101A, hlm. 4].

Another example which can be observed through the use of spells is in text MS1380 which explains the ways to do tawajjuh with the master so that the master will assist the pupil to shoot on target. The text says ".... It is worth mentioning here that the text is somewhat interesting because the pupil cited the names of his five teachers. The names indicate the influence of Persia or India. The spells are articulated by the pupil moments prior to the actual handling of the rifle.

\section{b. The Concept of Seven Dignities}

The use of this concept is obvious when connecting the practices of shooting to the thought of seven dignities through the tajalli principle. However, the description of the text does not comprise the seven dignities. In fact, the text only describes the second part of the tajalli principle beginning with the phrase " "allam arwāh" (spiritual world), "'ālam mithāl" (imaginary world), "'ālam ajsām" (material world) and "ălam insān" (real world). The example can be observed in text MS101B page 3-4:

“...yang menghimpunkan segala jalan yang empat jalan itu serta memakai dia itu ke kanan dan ke kiri dan ke atas dan ke bawah itu pertengahan saja diumpamakan ruh dengan alam, dimisalkan bedil itu 'àlam ajsām dan peluru itu laksyana 'ālam arwāh, dan ubatnya itu laksyana 'ālam mithāl $|[. .]$. $|[\ldots]|$ dan yang memegang itu laksyana 'álam insān. Maka adalah yang menghimpunkan segala misal itu pendekar orang ahlu' l-ma'rifat kerana ia seperti barzakh yakni 'àlam mithāl. Adapun 'ālam mithāl itu antara 'ālam arwāh dan 'ālam ajsām seperti kata ahlu' l-ma'rifat, karamlah aku antara tanzīh dan tasybīh. Adapun kesempurnaan ma'rifat itu antara tanzīh dan tasybīh semperti kata ahl al-ma'rifat, syarat tembak yang empat itu kita fikirkan jangan sekali kita melengkan, maka sempurna menembak kita. Inilah syarat yang dipetuakan oleh guru kita yang arif lagi bijaksakna, masuklah ma'rifat kita campurkan dengan ma'rifat yang diterima daripada guru kita yang 'ârif
bi'Llāh itu kira-kiranya ilmu ma'rifat ini menghasilkan ia memberi tembak atawa barang sebagainya."

“... (the things) that combine the four worlds and that move them to the right or to the left, upward and downward; in the center it is associated with spirit and nature. The rifle is associated with 'ālam ajsām, the bullet is associated with 'ālam arwāh, the gunpowder with the 'âlam mithāl $|[\ldots]|$ $|[\ldots]|$, and the shooter with the 'alam insān. The one who performs the action is called an advocate of ahlu'l-ma'rifat like barzakh, namely, 'àlam mithāl. The 'àlam mithāl resides between 'ālam arwāh and 'àlam ajsām as it is depicted in the ahlu'l-ma'rifat, and I sink between tanzīh and tasybīh and it is here where perfection of the ma'rifat rests. Never ignore the requirements of the shooting for the sake of perfection of our shot. These are the requirements advised by our wise master. If we follow them, we will find our ma'rifat blended with the master's ('ārif bi'Llāh) ma'rifat. Therefore, this knowledge of ma'rifat will produce a competency in shooting and others."

The above quotation shows two important points. First is the usage of term in the tajalli principle that becomes the symbol of understanding the physical entities, namely, the bullet, rifle, ammunition, and the shooter. The four undoubtedly are the obligatory conditions that have to be met in order that the act of shooting works. Second deals with four dignities related to intention of achieving ma'rifat. The process of achieving this ma'rifat is crucial for the sake of shooting precision. This indirectly mentions the concept of ma'rifat (which results in an insān kāmil: 'a perfect man') which is connoted with the objective of shooting, that is, the perfect shot through the belief in the four principles (ma'rifat in the practice of shooting is an unfathomable knowledge). It is supported by the master's rabitat, which can help the pupil make a perfect shot.

\section{c. The Symbolism of Letters}

Ahmat Adam reveals that many of Sufi idioms were included in the writing of Malay 
manuscripts dealing with philosophical mysticism. The idioms make use of certain concepts such as "light' or "heart" and relate them to specific symbols. Mystical symbols are, beyond doubt, parts of the doctrine of philosophical mysticism (Adam, 2009b: 8).

In line with this, the use of idioms in the form of specific letters is also found in the KNIB. Schimmel (2000: 519-541) claims that each letter has characteristics and functions. The uses of letters “dal" (د), "ha" (॰), "alif" (।), and so on represent a certain symbols in the philosophical mysticism. For example, a hint at how to stand upright for shooting position "has to look like an alif". The hint here is that "alif" symbolizes the name of God and therefore it is associated with chant in praise of God (Allah). The state of remembering God in such position is believed to accoutre the shooters to achieve precision in shooting. Another example involves the usage of "lam jalālat" or "lam alif" (ע) representing the pronunciation of shahadat (the Muslim confession of faith) là ilāha illa'Llāh. The letter is used when aiming through the sight by imagining the tiny hole of the sight as similar to that of the circle of the lower part of the "lam alif". In other words, it is as if this tiny circle of the lower part of the "lam alif" is the real sight and, if done that way, the shooting will be perfect.

\section{d. The Concept of Four Paths}

The concept of "Four Paths" relates to the four basics in the mysticism referring to shari'at, tarīqat, haqiquat and ma'rifat. Within the KNIB, they are considered as fundamentals in order to comprehend what shooting truly is about. In other words, the concept is employed to explain the philosophy of using firearms, starting from handling the rifle, observing and aiming the target, concentrating, to pulling the trigger. The four paths are elaborated in the Text 85.48, page 17-20:

“...ketahui olehmu talib, apa yang dinamai syariat. Bahawasanya syariat tembak itu atas perbuatannya diri yang zahir dan yang takluk kepada rukunnya dan seperti gamaknya dan adatnya dan barang yang demikian itu. Adapun tarikatnya itu atas dua jalan. Suatu jalan am dan kedua jalan arif dan tarikatnya pada am itu daripada mata yang zahirnya lalu kepada belahan pejera yang keduanya dan disatukan pada barang yang ditujunya. Adapun tarikatnya pada arif itu itu daripada mata hati datang kepada gamaknya lalu kepada nazarnya, dan nazar itu berlaku dengan yakin sematamata berlakulah yakin itu atas suatu yang dikehendakinya. Adapun hakikatnya itupun atas dua jalan juga, dan hakikatnya pada segala am itu perseninya pandangan dihimpunkan atas syarat petiknya. Adapun hakikat pada segala arif itu bahawasanya kejadian segala alim itu daripada ilmu haqq Allāh Ta'āla dan dinamai ilmu itu hakikat Nabi kita Muhammad șalla'Llāhu 'alayhi wasallam, dan pejera hakikatnya itu thābit pada diri kita yang batin, dan daripada itulah maka diperoleh tabiat diri yang batin itu daripada hakikat Nabi kita Muhammad. Apabila terpakainya pakaian yang demikian itu maka dapatlah ia menghidupkan orang yang mati, dan dapatlah ia menyempurnakan barang kehendaknya dan tiadalah terlindung pada barang halnya karena berlaku kehendak segala hamba-Nya itu dengan kehendak Allah dan demikianlah pandang segala arif, dan bedilnya dan ubatnya dan pelurunya dan yang dikehendakinya daripada suatu tembaknya nyata di dalam rahsia seperti segala alim di dalam ilmu haqq Ta'àla dan pada tatkala firman-Nya: 'kun', maka jadilah semesta sekelian alam. Dengan firman-Nya 'kun' itulah lengkap jadi dan demikian lagi pada segala arif pun berlaku segala kehendak-Nya dan rahsia-Nya yang sempurnanya juga karena terhimpun semesta sekelian alam kepada rahsia-Nya yang arif dan barang yang dikehendakinya hasillah. Adapun ma'rifat itu pun atas dua halnya juga dan ma'rifat-nya yang am ini mengenal ia kesalahan dirinya dengan sebab salah tembaknya, dan adapun ma'rifat yang arif itu dikenalnya segala rahsianya tembak itu daripada zahirnya dan batinnya tiada terlindung daripada ilmunya karena sekeliannya terhimpun pada ilmu segala arif, wa'Llāhu a 'lam. Adapun syarat segala arif itu menyucikan yakin dan nazarnya dan tiliknya dan tiadalah was-was dan sangka 
lagi karena sudah diputuskan oleh ma'rifat yakinnya yang suatu, wa'Llāhu a lam."

“... you, the knowledge seeker, must know what is called shari'at (guidance). The fact is that the guidance of shooting is a visible action and it bows to the directives such as estimation and procedures. The tariqqat itself consists of two paths: the general ('âm) and the wise ('ârif) path. While the physical eyes aim at the target in the general path, in the wise path the innermost feelings assist the estimation and the shot will be on target. And the target is something that is really desired. As for the haqiqat, there are also of two paths. The general haqiqat is related to ways to pull the trigger. The wise haqiqat deals with a situation of being totally humble before the knowledge, the rights belonging to God, and is called as the haqiqat of prophet Muhammad SAW. And the sight principally bows to the inner self form which we can gain action of the inner self of our prophet Muhammad SAW. If someone has reached that point, he can resurrect a dead body and he can make perfect whatever he desires. In this case, he will not find any obstacles because his will be granted by God. The rifle, gunpowder, bullets, and the target bow to the power of God, just like when God says 'kun' when He created the universe. With God's saying 'kun', all perfect intentions and secrets will be in effect. Ma'rifat too consists of two kinds: the general ma'rifat dealing with knowing one's mistakes if he misses the target of the shooting and the wise ma'rifat dealing with the visible and invisible secrets of shooting. All of them are included to the prudent knowledge. And the whole requirements are to purify the goal/target and to get rid of the hesitation as they are already decided with ma'rifat, wa'Llähu a'lam.

Apart from the above mentioned elements, KNIB also includes a concept of symbol which is related to the technical application of the rifle use. It includes reciting passages from the Koran which is done to hope for gaining a perfect shot (precision).

The element of the philosophical mysticism in KNIB provides abundant understanding of the heart. It is corresponding to what Martin Lings says, "sufism is the heart-wakefulness" (in Adam, 2009b: 8). A pure heart will help someone get closer to God. In the framework of technological know-how of shooting, Malays warn us that the perfection of shooting does not simply depend on the sophisticated rifle in use; a pure heart plays a more important role because "... it is the heart that makes the target [and] that produces and makes any kinds of actions. What is visible to the eyes indicates the reflection of the invisible heart" (Text 85.48, page 38). Therefore, lessons in the text also directs the shooter to rid himself of his hesitation and prejudice. A faithful heart to God will produce a perfect shot.

\section{TECHNOLOGY AND MYSTICISM}

If technology is only pursued as a scientific arrangement for practical purposes, the manuscript will surely be of no importance at all. This viewpoint contradicts the information found in KNIB regarding traditional epistemology, which proves that knowledge is built on the basis of faith and belief. Malays view and interact with two worlds: the visible and invisible. It is through such interaction that the form of the perception is comprehended and employed as guidance, reference, and experience. The interaction and understanding of this perception give rise to what is called knowledge of culture (Borhan, 2000: 125-6). Such situation simply depicts the way the traditional Malays think: there is a dynamic interaction between physical and non-physical factors whose processes are understood through the symbolization system (Harun, 2006: 152-3). This is clearly portrayed in KNIB.

Etymologically speaking, technology means the summation of knowledge practiced to produce goods and its usage to fulfil the necessities of humankind within a community. Every group within that community has its own cultural situation and consequently their unique technological needs which in turn correspond to their cultural situation. In this case, technology is associated with systems of belief: philosophical mysticism. Several proofs designate that, in terms of technology, the 
traditional Malays combine physical processes with mystical ones (Koentjaraningrat, 1967: 264). In addition, the relation of the two contradictory aspects points to the benefit of the Malay language as medium of asserting their intelligence. Through KNIB, for instance, they obviously show that Malays are intelligent enough to understand thing which are abstract and treat them as contemplativeintuition, which is then conveyed in the forms of allegory and analogy. Furthermore, Malays also show a pragmatic nature. They can give a new and specific meaning expressing a way of life, based on the context (Ahmad, 2004: 4-11).

It can be said that the relation between the elements of philosophical mysticism and firearm technology signify a number of functions. Idealism of philosophy of the mysticism elements is an effort to strengthen the state of the indigenous knowledge which is embraced in the texts. In other words, the technical and technological aspects alone are arranged in a philosophical way so that the knowledge can be put into higher degree until these aspects are in accordance with the existence of the manuscripts as a treatise, that is, referential texts used as guidance and are believed. Such circumstances will increase the faith on the spiritual characteristics of the symbolized things.

In regard to the notion above, the acceptance of elements of philosophical mysticism can also make the mystical force stronger and deal with supernatural power. In addition to the faith "created" from the "philosophical" knowledge in question, the faith is as well strengthened by mystical power sources by means of symbols. Therefore, the use of letters in calculating the precision of shooting or pronouncing of spells which relate the concept of symbols in philosophical mysticism became the standard for technological effectiveness, for example, in estimating bullet velocity by writing a sign of letter on top of it.

The description given shows that elements of philosophical mysticism are viewed in a magical manner and pragmatic in nature. Is it done as an adjustment toward the old belief which makes Malays depend on magic-mysticism? Mohd Taib Osman claims the arrival of Islam in fact made the magical tradition stronger (Osman, 1989: 180; Mohamed, 2001: 122-3). The fact that Malays still refer to Malay texts on medicine, book of
$T i b$, and so on are clear proofs of this claim. Other instances are the practices of rituals in martial arts and certain performance arts, which are associated with the tarīqat in philosophical mysticism.

\section{CONCLUSION}

The technological aspects in KNIB are intertwined with beliefs. The elements of philosophical mysticism are the perfect embodiment of the knowledge included in the manuscripts according to the concept of the manuscript itself as the book of guidance (treatise). From physical sense, the elements are taken as pragmatic concepts in order to achieve material goals. On the one hand, technology contains the psychological impression because its use can give rise to a belief. However, it must be emphasized that knowledge in KNIB deals with importance on purity of the heart, in which the goal of fundamental mysticism continuously exists. The concept of perfection in pursuing knowledge in the manuscripts is analogous to insān kāmil in mysticism. Based on KNIB, while perfection is viewed in the context of making an accurate shot, the basis of the perfection is a reflection of the perfection of the heart. On the other hand, the elements of philosophical mysticism show that the pattern of Malay thoughts in the field of technology and Islamic civilization are credited for sharing meaningful information and intelligence.

This article has put forth some examples in order to illustrate the functions and the roles of philosophical mysticism elements through the Malay firearms technology practiced in the days of yore. It has also contributed significantly to the interpretation of the mystical texts. Although this genre of studies is still limited, this article hopes to present some basic ideas about the relations of the philosophical mysticism of the Malay manuscripts in a broader sense. As such, it can be treated as groundwork with plenty of room for expansion for the future studies pertaining to related topics and subjects.

\section{ACKNOWLEDGEMENT}

We would like to express our gratitude to Siti Radziah binte Mustafa, M.A. for proof reading this article. 


\section{BIBLIOGRAPHY}

\section{Manuscripts}

MS101A Kitab Tib (Book of Tib)

MS101B Kitab Tib (Book of Tib)

MS1380 Mantera Menembak (Spells on Shooting)

Manuscript 85.48 Petua Menembak Meriam Istinggar (Treatise on Firing the Canon and the Matchlock Gun).

\section{Other works cited}

Ahmad, Abdul Samad. (1984). Peluru Petunang, Kuala Lumpur: Dewan Bahasa \& Pustaka.

Halim, Ahmad Zuhairi Ab. (1999). Amalan Mistik dan Kebatinan Serta Pengaruhnya Terhadap Alam Melayu. Petaling Jaya: Tamadun Research Trust.

Adam, Ahmat. (2009a). Pentarikhan dalam Manuskrip Melayu. Prosiding Persidangan Antarabangsa Manuskrip Melayu 2009, Kuala Lumpur: Jabatan Sejarah Fakulti Sastera \& Sains Sosial dan Akademi Pengajian Melayu Universiti Malaya, Nov. 23-25, 2009.

Adam, Ahmat. (2009b)." Unsur Tasawuf dalam Penulisan Warkah Melayu Lama”, Seminar Bulanan Naskah Melayu ke-4 2009, Jabatan Sejarah Fakulti Sastera \& Sosial dan Akademi Pengajian Melayu Universiti Malaya, Bilik Sumber Jabatan Sejarah, April 24, 2009.

Al-Hassan, A.Y. (1986). Islamic Technology; an Illustrated History, Paris: UNESCO \& Cambridge University Press.

Andaya, L.Y. (1999). Interaction with the Outside World and Adaptation in Southeast Asian Society 1500-1800. the Cambridge History of Southeast Asia (ed. Nicholas Tarling). Cambridge: Cambridge University Press, 1999, pp. 1-57.

Crawfurd, J. (1974). A Descriptive Dictionary of the Indian Islands and Adjacent Countries. India: Chaukambha Orientalia.

Ensiklopedia Sejarah dan Kebudayaan Melayu. Kuala Lumpur: Dewan Bahasa \& Pustaka, 1995.

Gibson-Hill, C.A. (1953). Notes on the Old Cannon Found in Malaya, and Known to be of Dutch Origin. Journal of the Malayan Branch Royal Asiatic Society, 26(2), 1953, pp. 145-74.

Gullick, J.M. (1978). Sistem Politik Bumiputera Tanah Melayu Barat. Kuala Lumpur: Dewan Bahasa \& Pustaka.

Harun, Hairuddin. (2006). Kosmologi Melayu dalam
Era Teknologi Maklumat. Kuala Lumpur: Dewan Bahasa \& Pustaka.

Hassan, Hamdan. (1988). Pengaruh Pemikiran Tasawwuf dalam Karya Sastera dan Budaya Melayu. Seminar Usuluddin, Jabatan Usuluddin, Akademi Pengajian Islam Universiti Malaya, Feb. 20-21, 1988.

Harisson, T. (1969). Brunei Cannon: Their Role in Southeast Asia (1400-1900 A.D.). Brunei Museum Journal, 1(1), pp. 94-118.

Piah, Harun Mat et.al. (2006). Kesusasteraan Melayu Tradisional. Kuala Lumpur: Dewan Bahasa \& Pustaka.

Purwana, Bambang Hendarta Suta. (2001). Pendekatan Hermeneutik dalam Penafsiran Teks Sastra Islam Melayu. Jurnal Humaniora, Vo. XIII, No. 1, pp. 82-89.

Ahmad, Hassan. (2004). Bahasa dan Pemikiran Melayu; Tradisi dan Kesinambungannya. Pemikiran Melayu: Tradisi dan Kesinambungan. Kuala Lumpur: Dewan Bahasa \& Pustaka, 2004, page 1-12.

Johns, A.H. (1974). Tentang Kaum Mistik Islam dan Penulisan Sejarah. Islam di Indonesia (ed. Taufik Abdullah), page 116-41.

Istanti, Kun Zachrun. (2001). Hikayat Amir Hamzah: Jejak dan Pengaruhnya dalam Kesusastraan Nusantara. Jurnal Humaniora, Vo. XIII, No. 1, pp. 22-29.

Khan, I.A. (1996). Coming of Gunpowder to the Islamic World and North India: Spotlight on the Role of the Mongols. Journal of Asian History, 30(1), pp. 27-45.

Koentjaraningrat. (1967). Beberapa Pokok Antropologi Sosial. Jakarta: Penerbit Dian Rakyat.

Manshur, Fadlil Munawwar. (1999). "Tasawuf dan Sastra Tasawuf dalam Kehidupan Pesantren", Journal Humaniora, Vol. 11, No. 1, pp. 102109.

McNair, J.F.A. (1972). Perak and the Malays. Kuala Lumpur: Oxford University Press.

Ali, Mohd Kassim Hj. (1995). Sejarah dan Perkembangan Senjata Orang Islam. Purba, 14, pp. 113-26.

Osman, Mohd Taib. (1989). Agama dan Kepercayaan Orang Melayu: Organisasi dan Struktur. Masyarakat Melayu: Struktur, Organisasi dan Manifestasi. Kuala Lumpur: Dewan Bahasa \& Pustaka. pp. 146-203.

Mohamed, Noriah. (2001). Aksara Jawi: Makna dan Fungsi. Sari (19), pp. 121-31.

Reid, A. (1969). Sixteenth Century Turkish Influence in Western Indonesia. Journal of Southeast Asian History, 10(3), pp. 395-414.

Zain, Shaharir Mohamad. (2005). Sains dan Teknologi 
Melayu Sebelum Dikuasai Penjajah dari Eropah. Kepustakaan Ilmu Tradisional. Kuala Lumpur: Dewan Bahasa \& Pustaka, 2005, pp. 159-213.

Schimmel, A. (2000). Dimensi Mistik dalam Islam (terj.). Jakarta: Pustaka Firdaus.

Soegondo, B. (1954). Ilmu Bumi Militer Indonesia, jil.2. Kebon Sirih: Pembimbing.

al-Attas, Syed Muhammad Naquib, Islam dalam Sejarah dan Kebudayaan Melayu, Kuala Lumpur: ABIM, 1992.
Trimingham, J.S. (1971). The Sufi Orders in Islam. Oxford: Clarendon Press.

Woolley, G.C. (1998). Malay Cannon. The Keris and Other Malay Weapons. Kuala Lumpur: Malaysian Branch of the Royal Asiatic Society. pp. 175-80.

Borhan, Zainal Abidin. (2000). Rumah Tradisi Melayu: Pandangan Dunia dan Orientasi Kosmologi Melayu. Kosmologi Melayu. Kuala Lumpur: Akademi Pengajian Melayu Universiti Malaya, pp. $125-42$. 